\title{
EFFICIENCY OF SUBSIDIES ALLOCATION \\ TO AGRICULTURAL ENTERPRISES IN THE REPUBLIC OF MOLDOVA
}

\author{
Ina DOMBROVSCHI', PhD in Economics, \\ State Agrarian University of Moldova
}

\author{
DOI: https://doi.org/10.36004/nier.es.2020.1-05 \\ JEL Classification: H25, J43, E22, Q12, Q14, Q18 \\ UDC: 631.155.6(478)
}

\section{ABSTRACT}

As the Republic of Moldova has limited opportunities to provide generous financial support to farmers, it is extremely important to efficiently use subsidy means, so as to contribute to the development and modernization of agriculture and rural areas. The development of agriculture in a dynamic way can be achieved on the basis of an efficient subsidy system, administered, monitored and evaluated. The aim of the research is to analyse and evaluate the efficiency and impact of subsidization on the development of the agricultural sector and to ensure a stable increase in agricultural production, emphasizing main support measures in this direction. To carry out this study, various research methods were used, such as: observation method, table method, analysis and synthesis method, comparison method, monographic method, statistical data collection. This article presents an analysis of the evolution of the subsidy fund for agricultural producers, which has increased 2.25 times in the last 7 years. There has also been analysed the structure of beneficiaries of subsidies according to the legal organizational form, who received subsidies during the reference period. It has been found that households are in the top of beneficiaries of subsidies who had a share of 62.03\% in 2018. The distribution of subsidies by development regions and per one hectare of agricultural land in the profile of development regions has been studied and it has been found that the predominant share is held by agricultural enterprises in the Centre region, about 38.9\% of the means of the subsidy fund. The results of the research show an increase in the subsidy level, through support measures. In this context, we can mention that the support measures must ensure an efficient use of the subsidies.

Keywords: financial result, efficiency, subsidies, investments, subsidy fund, support measures, subsidy means.

În condițiile în care Republica Moldova are posibilități limitate de a acorda un suport financiar generos agricultorilor, este extrem de important utilizarea eficientă a mijloacelor de subvenționare, astfel, încât să contribuie la dezvoltarea și modernizarea agriculturii și spațiului rural. Dezvoltarea agriculturii pe cale dinamică poate fi realizată în baza unui sistem eficient de subvenționare, administrat, monitorizat şi evaluat. Scopul cercetării constă în analiza și evaluarea eficienței și impactului subvenționării asupra dezvoltării sectorului agricol și asigurării unei creșteri stabile a producției agricole, accentuând în această direcție principalele măsuri de sprijin. Pentru realizarea acestui studiu s-a apelat la diverse metode de cercetare precum: metoda observării, metoda tabelelor, metoda de analiză și sinteză, metoda comparațiilor, metoda monografică, preluarea statistică a datelor. În prezentul articol, se regăsește o analiză a evoluției fondului de subvenționare a producătorilor agricoli, care, în ultimii 7 ani, a înregistrat o creștere de 2,25 ori. De asemenea, s-a analizat structura beneficiarilor de subvenții după forma organizatorică juridică, ce au accesat subvenții în perioada de referință, se constată că gospodăriile țărănești sunt în topul beneficiarilor de subvenții care, în anul 2018 dețin o cotă de 62,03\%. A fost studiată repartiția subvențiilor pe regiuni de dezvoltare și la un hectar de teren agricol în profilul regiunilor de dezvoltare și s-a constatat că cota preponderentă o dețin întreprinderile agricole din regiunea Centru, circa 38,9\% din mijloacele fondului de subvenționare. Rezultatele cercetării constată o creștere a nivelului de subvenționare, prin intermediul măsurilor de sprijin. În acest context menționăm, că măsurile de sprijin trebuie să asigure o utilizare eficientă a mijloacelor de subvenționare.

Cuvinte-cheie: rezultat financiar, eficiență, subvenții, investiții, fond de subvenționare, măsuri de sprijin, mijloace de subvenționare.

\footnotetext{
1 C Ina DOMBROVSCHI, dombrovschi@mail.ru
} 
В условиях, когда Республика Молдова имеет ограниченные возможности предоставления значительной финансовой помощи фермерам, очень важно использовать дотации эффективно, чтобы повлиять на развития и модернизацию сельского хозяйства и сельской местности. Развитие сельского хозяйства в динамике можно осуществить на основе эффективной системы дотаций, управляемой, наблюдаемой и оценённой. Цель исследования состоит в анализе и оценки эффективности и влиянии дотаций на развитие сельского хозяйства и обеспечения стабильного роста сельскохозяйственной продукции, акцентируя в этом направлении основные меры поддержки. В данном исследовании были использованы различные методы: наблюдение, метод таблиц, метод анализа и синтеза, метод сравнений, монографический метод, статистическая обработка данных. Был осуществлен анализ эволюции фонда дотаций сельскохозяйственных производителей, который в последние 7 лет зарегистрировал рост в 2,25 раза. Также, был сделан анализ структуры бенефициаров дотаций по организационно-юридической форме, где установлено что фермерские хозяйства в 2018 году удерживают 62,03\%. Было исследовано распределение дотаций по регионам развития и на гектар сельскохозяйственных площадей в профиле регионов развития и установлено что наибольшую долю удерживают сельскохозяйственные предприятия из региона Центр (38,9\% из средств фонда дотаций). Результаты исследования показывают рост уровня дотаций, как меры поддержки. Важно подчеркнуть, что меры поддержки должны обеспечить эффективное использование средств дотаций.

Ключевые слова: финансовый результат, эффективность, дотации, инвестиции, фонд дотаций, меры поддержки, средства дотаций.

\section{INTRODUCTION}

The major objective of agricultural enterprises is determined by the ever-increasing requirements of the population and of the processing industry for agricultural products, and also by the economic and financial results. The achievement of the objective in question is conditioned by the pursuit of a profitable activity based on a reasoned system of state support. This support system is manifested by the allocation of subsidies from the state budget to stimulate investment in the agricultural sector. Subsidies are a form of government support for agricultural enterprises and households to supplement their incomes, stimulate the production of agricultural products and influence the cost of these products, and subsidies are a considerable source of coverage for agricultural production costs.

The issue of subsidizing the agricultural sector has recently become relevant in the Republic of Moldova, being addressed in various scientific papers of local researchers. Among the local researchers who studied this subject we can mention Tomița P., Litvin A., Cimpoieș L. and others (Tomița 2013; Litvin 2013; Cimpoieș 2013). The mentioned authors referred to the issues related to the structure and role of the subsidy, to the targeting of support measures, as well as to the aspects of the subsidy in the Republic of Moldova in correlation with other European countries. But at the same time, we consider it necessary to argue the effectiveness of the means of subsidization in agricultural enterprises. Based on the above, the aim of the research is to analyze and evaluate the efficiency and impact of subsidization on the development of the agricultural sector and to ensure a stable increase in agricultural production, emphasizing the main support measures in this direction.

\section{DATA SOURCES AND METHODS USED}

The informational and statistical support of the investigations was provided by the legislative acts of the Republic of Moldova, generalizing data of the National Bureau of Statistics of the Republic of Moldova, Agency for Interventions and Payment for Agriculture, Ministry of Agriculture, Regional Development and Environment of Moldova, Agency for Land Relations and Cadastre. The concepts of economists from the country and abroad served as methodological support.

The following research methods were used in the stady: observation method, table method, analysis and synthesis method, comparison method, monographic method, statistical data collection.

\section{RESULTS OF OWN RESEARCH AND DISCUSSIONS}

Subsidies in agriculture are a widespread phenomenon that is used practically in all the countries. The highest level of subsidy among European countries was registered in Norway, Switzerland and Iceland, where subsidies make up $65-75 \%$ of the agricultural production value. The average rate of 
subsidies in the European Union (EU) is 35\% of the agricultural production value (Tomita 2013: 73).

Subsidizing the agricultural sector in the Republic of Moldova has become the most debatable topic, as the pace of growth of the national economy directly depends on the economic growth in agriculture, a branch that covers more than $30 \%$ of the republic's jobs.

In these conditions, in order to move agriculture and rural area on a more dynamic path of development, it is necessary to promote them through subsidies (AIPA 2018, 2019):

- Measures to stabilize agricultural production by protecting agricultural activities from unfavorable climatic factors such as prolonged drought, which is a common phenomenon;

- Measures to stimulate agricultural activities to replace imports with competitive domestic products that can compete with imported products;

- Measures to change the structure of agriculture that should focus on high value-added products which means there should be made a list of products and activities that are considered to provide high added value and to allocate special resources in this direction;

- Measures to protect the rural environment, first of all the soil in all activities in the rural area, not only the agricultural ones;

- Subsidy measures should focus on agricultural production with export potential, and especially on those high value-added products that do not cover domestic consumption needs such as potatoes, vegetables, fruits, meat and milk;

- Measures to develop and support complex businesses with the involvement of several activities of the value chain.

The implementation of subsidy measures will have an impact on increasing incomes of agricultural producers, will create favorable conditions for households. At the same time, these subsidy measures will help increase opportunities for business development in rural tourism.

A high level of mobilization of financial resources to subsidize the agricultural sector has been registered during the last 7 years. Thus, in the period 2012-2018, the subsidy fund with the contribution of external development partners registered a high increase from 400 million lei in 2012 to 900 million lei in 2018 (figure 1).

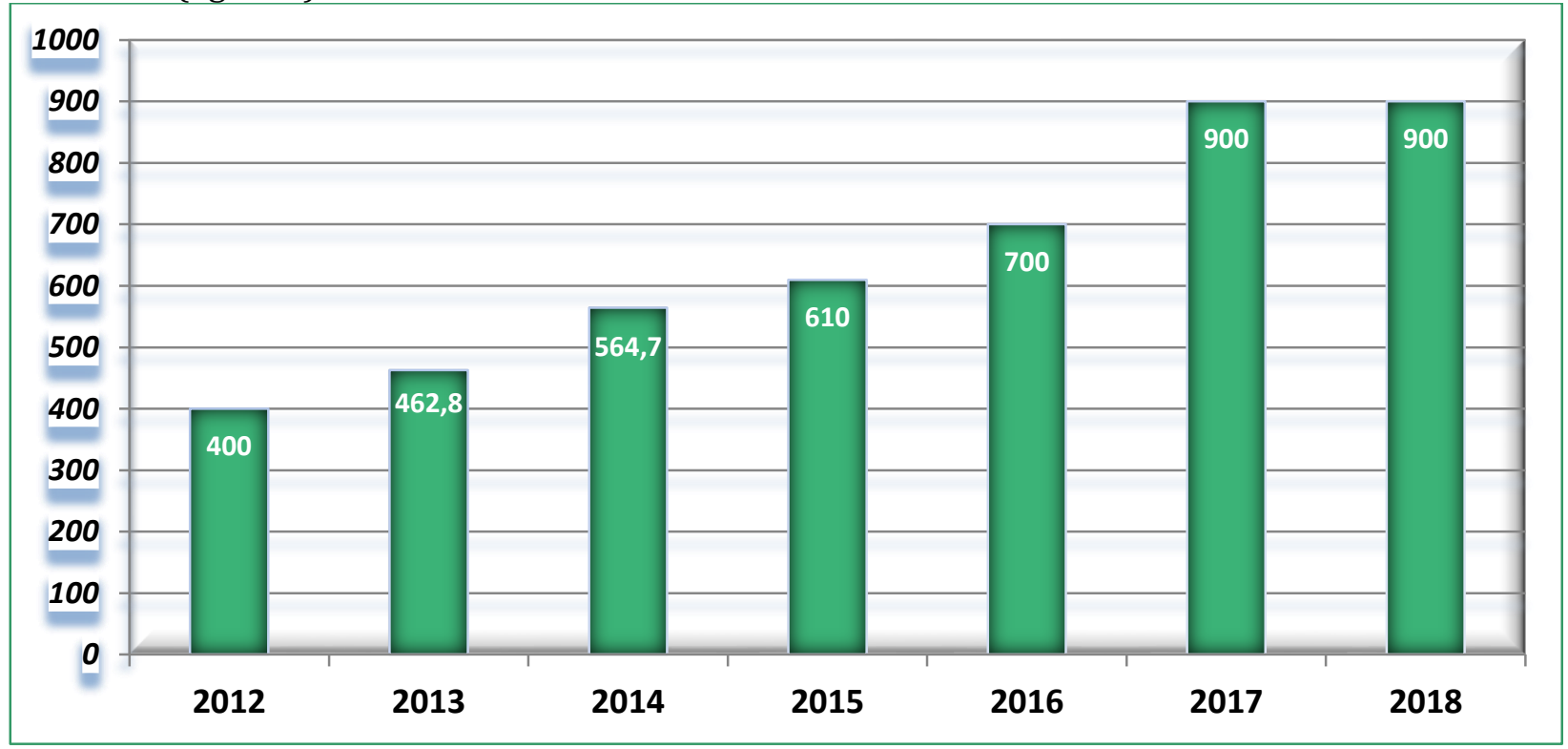

Figure 1. Evolution of the subsidy fund for agricultural producers in the Republic of Moldova, million lei

Source: Elaborated by the author based on the Agency for Intervention and Payments in Agriculture.

The data presented in figure 1 show an increase of the subsidy fund in 2018 compared to 2012 by 500 million lei or 2.25 times.

We would like to mention that one of the biggest challenges is the inability of the Agency for 
Intervention and Payments in Agriculture (AIPA) to meet its financial obligations to all grant beneficiaries, because the agency pays on average about $70 \%$ of the total amount of subsidies authorized for the management year, the rest being transferred for the following budget year (figure 2).

From the graphic presentation we can notice that from the subsidy fund for 2018 the agricultural producers were financed in proportion of $70.2 \%$. An essential share is constituted of the arrears for 2017, which make up $24.6 \%$ of the authorized amount. The contribution for the National Fund for Vine and Wine and the expenses for the administration of the National Fund for Agriculture and Rural Development (NFARD) constituted respectively 3.2\% and 2.0\%.

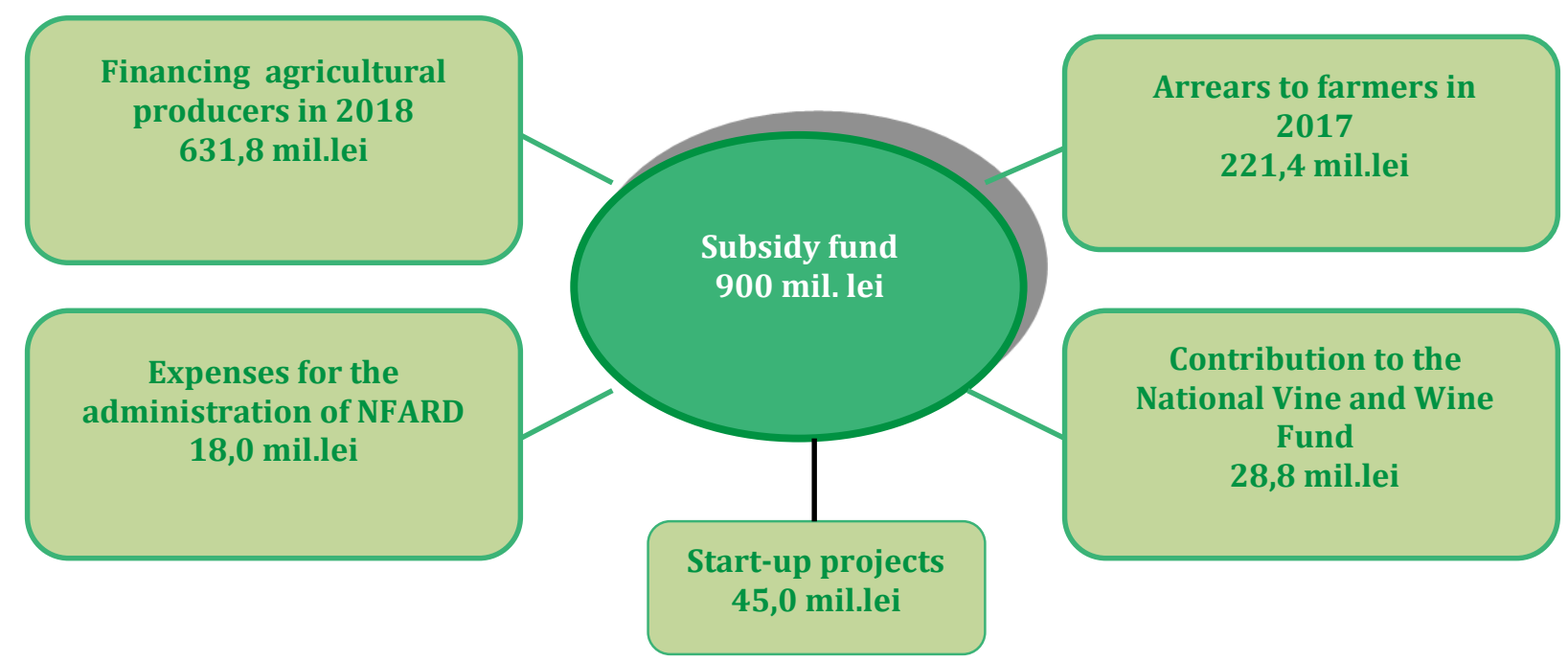

Figure 2. Distribution of NFARD in 2018

Source: Prepared by the author on the database of the Agency for Intervention and Payments in Agriculture

Thus, late payments to beneficiaries are the main problem. Solving this problem requires the grant fund to have a stable amount over several years that would allow $100 \%$ funding regardless of current budget revenues.

The volume and structure of subsidies must correspond to the development objectives stipulated in the National Strategy for Agricultural and Rural Development for the years 2014-2020 and contribute to the efficient use of subsidy means. The usefulness and relevance of the grant mechanism can be appreciated from the perspective of the support provided to the implementation of this strategy, which is limited to ensuring three objectives (Strategy 2014-2020):

1. Food security of the country;

2. Production of agricultural products with high added value;

3. Sustainable use of financial resources.

In the context of ensuring the country's food security, subsidizing agricultural producers can be geared towards supporting three main directions:

1. Research on new production technologies;

2. Promoting and implementing measures to adapt and mitigate the effects of climate change on agricultural production;

3. Supporting efforts to diversify the food balance (in the case of our country, ensuring the internal resources of the necessary vegetables, meat and dairy products).

The national strategy for agricultural and rural development for the years 2014-2020 expects the diversification of beneficiaries of subsidies and an increase in investments from 3 billion lei per year (in 2012) to about 4 billion in 2020 (Strategy 2014-2020:86).

As an argument for the implementation of the strategic objectives we can see the diversification of the beneficiaries according to the form of legal organization (table 1). 


\section{Distribution of the subsidy fund according to the forms of organization of agricultural enterprises in 2018}

\begin{tabular}{|l|c|c|c|c|}
\hline \multicolumn{1}{|c|}{ Type of organization } & $\begin{array}{c}\text { Number of } \\
\text { beneficiaries }\end{array}$ & $\begin{array}{c}\text { Share, } \\
\%\end{array}$ & $\begin{array}{c}\text { Authorized } \\
\text { amount of } \\
\text { subsidies, } \\
\text { mil. lei }\end{array}$ & $\begin{array}{c}\text { Share, } \\
\%\end{array}$ \\
\hline 1. Joint-stock company & 43 & 0,97 & 41,9 & 4,34 \\
\hline $\begin{array}{l}\text { 2. Agricultural production } \\
\text { cooperative }\end{array}$ & 111 & 2,52 & 71,1 & 7,37 \\
\hline 3. Limited liability company & 1418 & 32,15 & 582,7 & 60,42 \\
\hline 4. Peasant household & 2736 & 62,03 & 252,1 & 26,14 \\
\hline 5. Sole proprietorship & 73 & 1,65 & 12,9 & 1,34 \\
\hline 6. State enterprise & 3 & 0,07 & 0,3 & 0,03 \\
\hline 7. Public association & 22 & 0,50 & 2,8 & 0,30 \\
\hline 8. Limited partnership & 5 & 0,11 & 0,6 & 0,06 \\
\hline $\begin{array}{l}\text { 9. Production and trade } \\
\text { company }\end{array}$ & 0 & 0 & 0 & 0 \\
\hline \multicolumn{1}{|c|}{ Total } & $\mathbf{4 4 1 1}$ & $\mathbf{1 0 0 , 0 0}$ & $\mathbf{9 6 4 , 4}$ & $\mathbf{1 0 0 , 0 0}$ \\
\hline
\end{tabular}

Source: Elaborated by the author on the database of the Agency for Intervention and Payments in Agriculture.

The data presented in table 1 show that in the structure of the beneficiaries of subsidies in 2018, the predominant share belongs to the peasant households - $62.03 \%$. More than $32 \%$ of the beneficiaries are limited liability companies. This fact reflects a change from the 2012-2015 average when limited liability companies and joint-stock companies owned $44 \%$ and peasant households and individual enterprises $-52 \%$. At the same time, the structure of the amounts authorized by subsidies show us that more than 582 million lei or more than $60 \%$ belongs to limited liability companies, while to the peasant households $-26.14 \%$.

Positive development in subsidy policies in recent years have resulted in the inclusion of agriculture in national development strategies as a priority sector and the drafting of the following legislation:

- Subsidy Regulation for the years 2017-2021;

- Government Decision on the distribution of funds of the National Fund for Agriculture and Rural Development (NFARD) no. 455 of 21.06.2017, no. 201-213.

The subsidy regulation for the years 2017-2021 stipulates the eligibility criteria for subsidizing agricultural producers and the ceiling (maximum amount) of subsidies in the profile of measures and sub-measures.

We believe that setting subsidy ceilings for each measure will ensure an efficient use of funds. The amounts granted to subsidizing measures are the most important means by which the money can be directed so as to achieve the development objectives of agriculture and rural area.

The research on subsidies granting has shown that the most important technical constraint is that the allocation takes place on an annual basis. This method has the following disadvantages:

- the farmer lacks the confidence that the measure will be in force the next year;

- it does not allow businesses to join development projects, because their implementation lasts more than a year;

- it allows corruption, because there exists the fear that the subsidies will not be paid later.

Taking into account these disadvantages and the need to improve the subsidy system, the Government has decided to change the way grants are awarded in 2017 on the basis of multi-annual programs, in which the objectives and subsidy measures remain stable. Thus, starting with 2017, the 
support measure "Stimulating investments in the acquisition of the No-till and Mini-till equipment" was introduced with an amount of 54.4 million lei. In the profile of support measures, the predominant share in 2018 belongs to the following measures:

- stimulating investments for the development of post-harvest and processing infrastructure 27.68\%;

- stimulating investments in the acquisition of agricultural machinery and equipment - $27.08 \%$;

- stimulating investments for the establishment, modernization and deforestation of multiannual plantations (including fruit and vineyards) - 20.36\%.

By the Government's decision, starting with 2017 the support measures will remain stable, which will allow the adjustment to the European practices, ensuring (GD 2017):

1. planning and establishing possible subsidy support measures in accordance with the National Strategy for Agriculture and Rural Development for a period of at least 5 years, thus ensuring continuity in the support of agricultural producers.

2. the activities of receiving, examining, inspecting, authorizing applications for grants and making payments shall be based on the following principles:

a. efficiency based on economic-financial arguments;

b. decisional transparency;

c. continuity of support processes for agricultural producers.

3. classification of agricultural producers in small, medium and large agricultural producers, criteria characteristic of the definitions were provided in Law no. 206-XVI of 07.07.2006 on the support of the small and medium enterprises sector, adapted to the peculiarities of the agricultural sector, being defined depending on the land areas processed by agricultural producers.

4. the implementation of a new system for monitoring the reasonability of investment costs, not to allow an artificial increase in the value of investments in order to unfairly benefit from higher subsidies, given that the investment subsidy is calculated from expenses incurred, confirmed by invoices, payments, and so on.

5. the size of the subsidies will not exceed $50 \%$ of the investment cost, and the agricultural producer under a measure will be entitled to the subsidy only once a year.

The Regulation also provides for the inclusion of two new support measures, namely the stimulation of promotion activities on external markets consists in the allocation of financial resources for supporting producer groups via agricultural professional associations in participating and organizing agri-food exhibitions, fairs, and competitions, including external markets' chains, to increase competitiveness and promote local agricultural and food products.

In addition, in order to encourage organic agri-food production, to support small and mediumsized businesses and to attract young people and women farmers to agriculture, subsidies in increased amounts are granted to (AIPA 2017):

a) young agricultural producers and women farmers $-15 \%$;

b) agricultural producers engaged in cultivating organic crops or breeding organic livestock $-20 \%$.

From the perspective of developing the competitive advantages of the agricultural sector and its integration in European and international trade, submeasure 1.6 "Stimulating investments for post-harvest and processing infrastructure development", corresponds mostly to the first objective of the National Strategy for Agriculture and Rural Development for 2014-2020 which consists in increasing the competitiveness of the agri-food sector through restructuring and modernization. Moreover, the level of concentration of subsidy applications is close to $35 \%$, and the share of the allocation of subsidized amounts varies from $22.6 \%$ in 2013 to $27.68 \%$ in 2018. In figure 3 we present the evolutionary nature of the means subsidized under submeasure 1.6 .

The data presented in figure 3 show us that despite the decrease in the allocated amounts from 141.3 million lei in 2014 to 76.4 million lei in 2015, within the period 2015-2017 an increasing trend is maintained. Thus, in 2017 the amount of subsidies for the development of post-harvest-processing infrastructure increased by 104.8 million lei or almost by 2.37 times compared to 2015. In 2018, there was a decrease in the allocated amounts from 181.2 million lei to 170.2 million lei. 


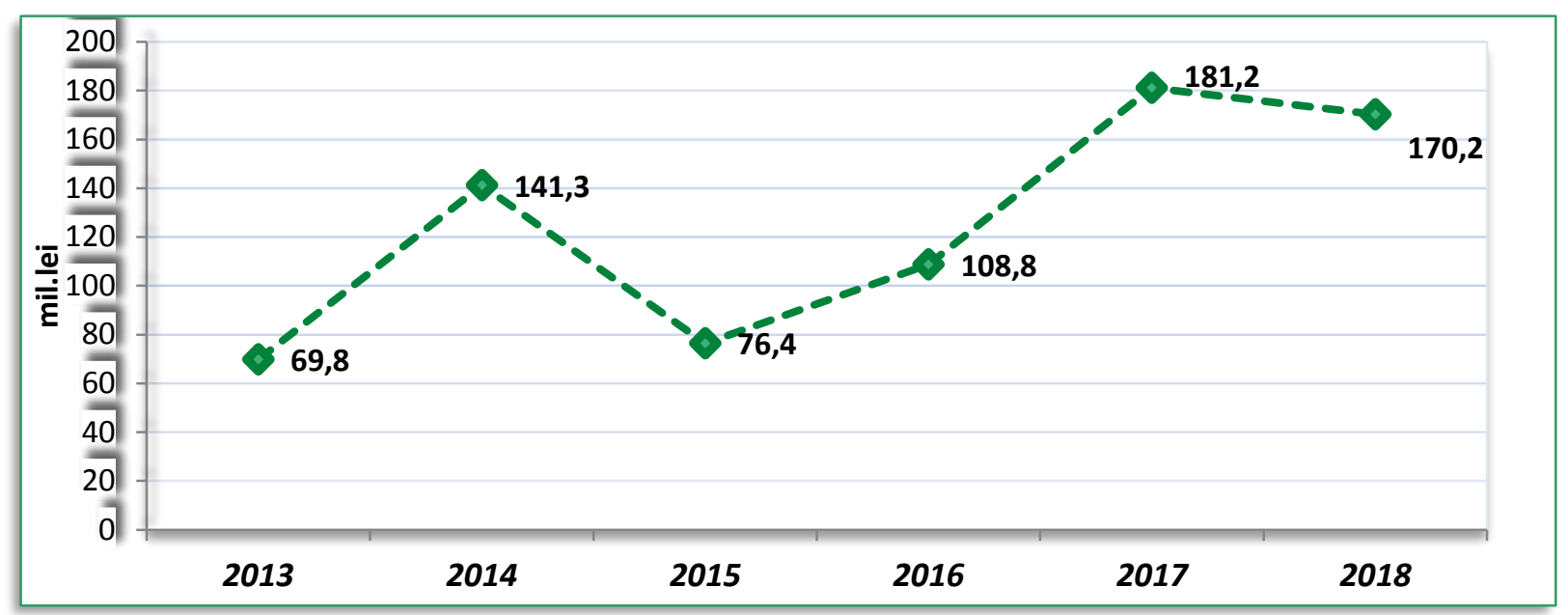

Figure 3. Dynamics of subsidized amounts aimed at stimulating investments for post-harvest and processing infrastructure development, mil. lei

Source: Elaborated by the author on the database of the Agency for Intervention and Payments in Agriculture

One of the most stable subsidy measures over the years is "Stimulating agricultural producers to take loans from financial institutions." The impact of this measure on increasing the competitiveness of agriculture is manifested by:

- boosting the use of credit by a large number of agricultural producers;

- increasing the profitability of the operational activity;

- increasing incomes of agricultural producers and reducing poverty in rural areas.

The subsidy regulation for the years 2017-2021 provides for the granting of loans to agricultural producers for purchasing the following goods and services:

- seeds and planting material;

- fuel;

- fertilizers;

- means of plant and animal protection;

- fodder;

- greenhouse modules, verandas, tunnels, film for greenhouses;

- equipment, agricultural equipment, irrigation systems, anti-hail equipment, etc.;

- technological equipment and machinery to develop post-harvest infrastructure and primary processing.

The maximum amount of credit for a beneficiary is 100 thousand lei, and for producer groups the credit ceiling is 300 thousand lei.

The subsidy for the purchase of refrigerators for storing fruits, vegetables, grapes will constitute (AIPA 2018): for a beneficiary - 3 million lei; and for producer groups - 4.5 million lei.

Based on the fact that the level of technical endowment of agriculture in the Republic of Moldova is low, one of the priority directions of subsidy is considered "Stimulating investments for procurement of agricultural machinery and equipment" whose share for the period 2013-2018 is on average $23.87 \%$. According to the data of the Agency for Intervention and Payments in Agriculture within the period 20122016 annually there were purchased over 1500 units of high capacity tractors, high precision seeders, and multi-operational grain harvesters. More than $20 \%$ of the total allocated resources are intended for the purchase of multifunctional combines for harvesting cereals, peas, and another $10 \%$ were allocated for baling, pressing of vegetable waste. Of the amount of subsidies for this measure, $10 \%$ was intended to purchase the No-Till and Mini-Till technology.

The analysis of the support measures and the allocated amounts shows that almost $80 \%$ of the total amount of subsidies effectively contributed to the achievement of the strategic objectives. Therefore, in order to increase the effectiveness of support measures, it is necessary to implement the subsidy instruments in more detail in order to make them more targeted.

The study on the allocation of subsidies in territorial profile allowed us to identify some 
discrepancies between development regions and administrative districts by the total volume of subsidies [5], their structure and the amount allocated in the calculation per hectare of agricultural land. On average in 2015-2017, most subsidies were allocated to the districts: Cahul (5.09\%), Comrat (5.18\%), Causeni (4.33\%), Hincesti (4.16\%), Ialoveni (3.94\%). The least subsidies were allocated to the districts: Basarabeasca (1.0\%), Vulcănești (0.9\%), Leova (1.3\%), Dubăsari (0.98\%). In the period 2015-2018, the ratio between the shares of districts with the largest amounts of subsidies compared to the smallest was from 3.9: 1.0 to 5.2: 1.0. The calculations showed us that the biggest beneficiaries of subsidies are the districts where the economic level of development is high, and the level of consultancy and information for agricultural producers was also high.

Table 2

Dynamics of subsidies calculated per 1 ha of agricultural land in the profile of the districts from the Centre region, lei

\begin{tabular}{|l|c|c|c|c|}
\hline \multicolumn{1}{|c|}{ Districts } & 2015 & 2016 & 2017 & $\begin{array}{c}\text { On average } \\
\text { 2015-2017 }\end{array}$ \\
\hline Anenii Noi & 297,46 & 244,91 & 402,86 & 315,1 \\
\hline Calarasi & 119,44 & 140,51 & 347,74 & 202,6 \\
\hline Criuleni & 150,50 & 534,06 & 502,28 & 395,6 \\
\hline Dubasari & 111,06 & 350,33 & 306,70 & 256,0 \\
\hline Hincesti & 216,82 & 245,45 & 326,13 & 262,8 \\
\hline Ialoveni & 312,67 & 483,99 & 528,76 & 441,8 \\
\hline Nisporeni & 497,04 & 243,32 & 368,69 & 369,7 \\
\hline Orhei & 221,03 & 244,81 & 321,30 & 262,4 \\
\hline Rezina & 88,96 & 192,43 & 291,40 & 190,9 \\
\hline Straseni & 422,54 & 416,02 & 400,34 & 413,0 \\
\hline Soldanesti & 242,54 & 280,61 & 536,32 & 353,2 \\
\hline Telenesti & 166,44 & 220,04 & 233,30 & 206,6 \\
\hline Ungheni & 177,53 & 228,82 & 386,72 & 264,4 \\
\hline Total & 232,62 & 294,25 & 380,97 & 309,3 \\
\hline
\end{tabular}

Source: Author's calculations based on information from the Agency for Intervention and Payments in Agriculture and the Agency for Land Relations and Cadastre.

At the same time, the calculations performed in table 2 attest to the existence of discrepancies in the amount of subsidies per hectare of agricultural land in the profile of the districts from the Centre region. Thus, on average for the years 2015-2017, the highest amounts of subsidies per hectare of agricultural land were received by the districts of Ialoveni - 441.8 lei, Straseni - 413.0 lei and Criuleni - 395.6 lei. And the districts with the lowest amounts of subsidies per hectare were: Rezina - 190.9 lei, Călărași -202.6 lei and Telenești -206.6 lei.

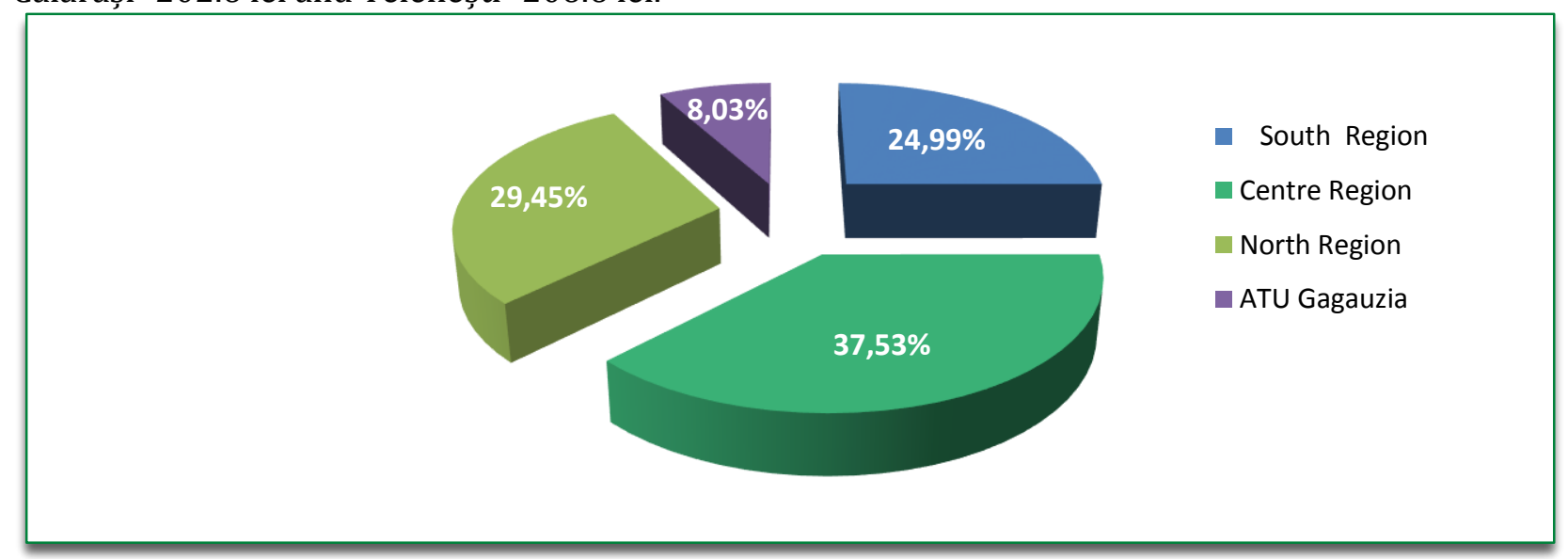

Figure 4. Distribution of subsidies in the profile of development regions within the period $2015-2018$ (in percentages)

Source: Elaborated by the author on the database of the Agency for Intervention and Payments in Agriculture

No. $1 / 2020$ 
Analyzing the distribution of subsidies by development regions on average for the period 20152018 (figure 4) we can see that the predominant share of the means of the subsidy fund belongs to the Center region-37.53\% which is explained by the increase of subsidized amounts per hectare of agricultural land in 2018 compared to the average $2015-2017$ by almost $37 \%$. The North Region in the reference period used $29.45 \%$ of the total amount of subsidies or $8.08 \%$ less than the Center region. The agricultural producers from the South region and ATU Gagauzia received respectively $24.99 \%$ and $8.03 \%$ of the means of the subsidy fund.

Calculations show that for each hectare of agricultural land in the period 2015-2017, the amount of subsidies on average for the republic is 261.2 lei, which is insufficient for the development of competitive agriculture (figure 5).

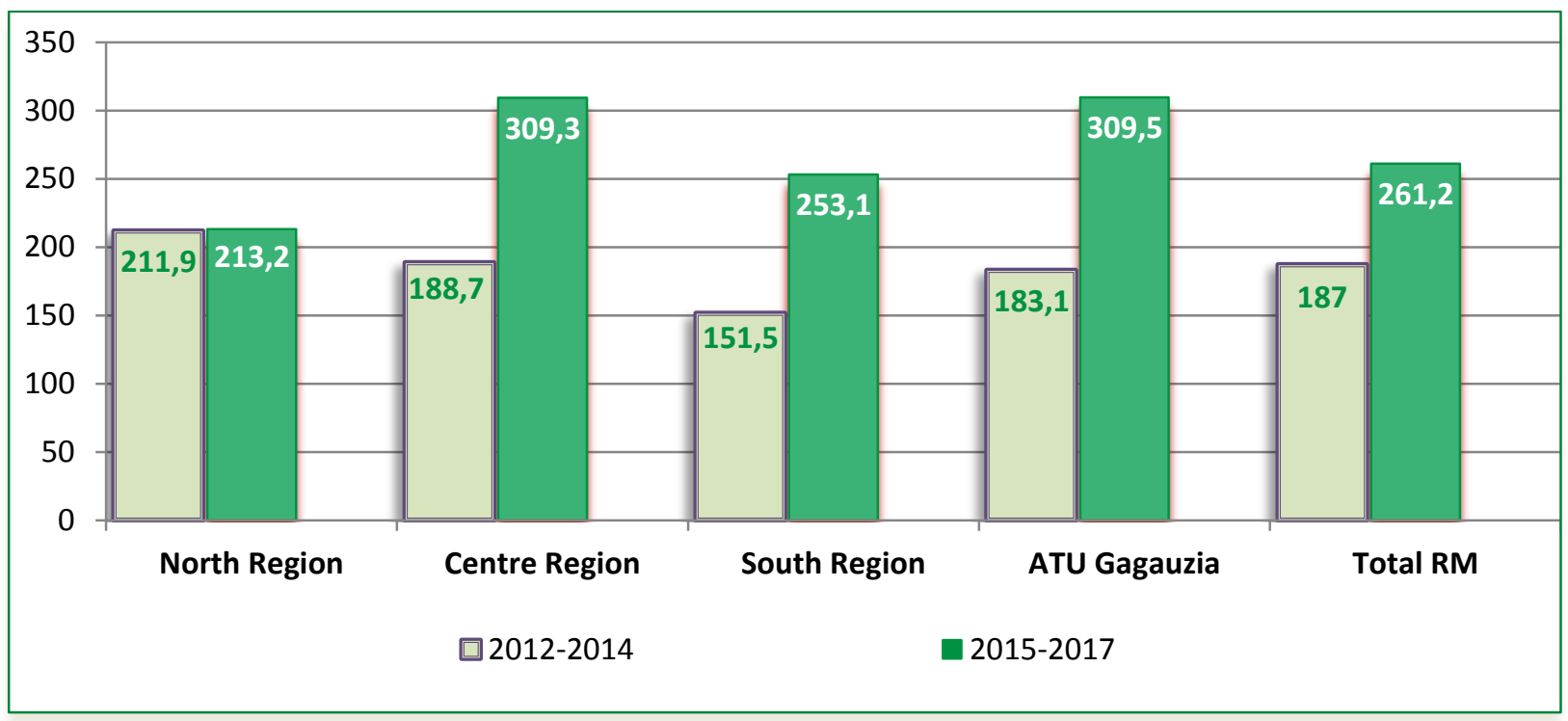

Figure 5. Dynamics of subsidies in calculation per hectare of agricultural land in the profile of development regions (lei/ha)

Source: Author's calculations based on the information from the Agency for Intervention and Payments in Agriculture and the Agency for Land Relations and Cadastre.

The level that exceeds the average subsidy per republic is attested in ATU Gagauzia -309.5 lei/ha and the Center region -309.3 lei / ha. In the South region it is attested that for every hectare of agricultural land in 2015-2017 there were allocated 253.1 lei or 7.9 lei less than the average per republic. The lowest level of subsidy was registered in the North region -213.2 lei/ha or 48 lei less than the average per republic.

The data presented in figure 5 show the dynamic increase of the subsidy level which is a result of the considerable increase of the subsidy fund in the period 2015-2017 compared to the period 2012-2014.

Regarding the economic efficiency, we can see the following:

- Comparing the growth rate of subsidies and sales revenues, we can notice that the growth rate of revenues is lower than that of subsidies by $8.85 \mathrm{pp}$, which shows that there is a reduction in the efficiency of using subsidies;

- The dynamics shows the reduction of revenues per one leu of subsidies in 2017 compared to 2016 by 5.22 lei or by $28.84 \%$.

\section{CONCLUSIONS}

In order to develop agriculture and rural areas in a more dynamic way, it is necessary to subsidize agricultural producers, which can promote a wide range of support measures and especially those related to the protection of agricultural activities from unfavorable climatic factors such as drought, which is a common phenomenon in our country. It has been found that in the last seven years 
the trend of subsidizing the agricultural sector has been upward. Thus, in 2018 compared to 2012, the subsidy fund increased by 500 million lei or 2.25 times. In the structure of the subsidies beneficiaries, the largest share of subsidies are accessed by Ltd (limited liability company) which, in 2018 , obtained subsidies in the amount of 582.7 million lei or $60.4 \%$ of the value of the National Fund for Agriculture and Rural Development, being followed by PH (peasant households) which received subsidies in the amount of 252.1 million lei or $26.1 \%$ of the value of the National Fund for Agriculture and Rural Development.

Analyzing the distribution of subsidies by development regions, we found out that within the period 2015-2018 the predominant share is held by agricultural enterprises in the Centre region $-37.53 \%$ of the means of the subsidy fund.

The calculations showed us that in the reference period the amount of subsidies per hectare of agricultural land constituted 261.2 lei on average for the republic, ATU Gagauzia - 309.5 lei / ha, the Centre Region -309.3 lei / ha, the North Region and the South Region respectively 213.3 and 253.1 lei/ha.

The research results show an increase in the dynamics of the subsidy level. At the same time with the increase of subsidies level, there is a reduction in economic efficiency, which is manifested by the decrease in sales revenues per one leu of subsidies. In the current situation, we consider that measures to monitor subsidies and their efficient use are necessary.

\section{REFERENCES}

1. AGENȚIA DE INTERVENȚII ȘI PLĂȚI PENTRU AGRICULTURĂ. Regulamentele de subventionare 2017-2021 [citat 01 iunie 2018]. Disponibil: http://aipa.gov.md/ro/content/regulamentele-desubventionare-2017-2021

2. AGENȚIA DE INTERVENȚII ȘI PLĂȚI PENTRU AGRICULTURĂ. Măsurile de sprijin aferente Regulamentului de subvenționare 2017-2021 [citat 14 iulie 2018]. Disponibil: http://www.aipa.gov.md/ru/node/1872

3. AGENȚIA DE INTERVENȚII ȘI PLĂȚI PENTRU AGRICULTURĂ. Posibilități de finanțare. [citat 09 septembrie 2018]. Disponibil: http://aipa.gov.md/ro/posibilitati-de-finantare

4. AGENȚIA DE INTERVENȚII ȘI PLĂȚI PENTRU AGRICULTURĂ. Rapoarte de activitate. [citat 03 septembrie 2018]. Disponibil: http://aipa.gov.md/ro/rapoarte

5. AGENȚIA DE INTERVENȚII ȘI PLĂȚI PENTRU AGRICULTURĂ. Liste beneficiari pe ani. [citat 10 septembrie 2018]. Disponibil: http://aipa.gov.md/ro/lista-benificiarului

6. Anuarul statistic al Republicii Moldova = Статистический Ежегодник Республики Молдова = Statistical Yearbook of the Republic of Moldova 2017. Chișinău: Biroul Naţional de Statistică al Republicii Moldova, 2017. 486 p. ISBN 978 9975-53-928-9.

7. BIROUL NAŢIONAL DE STATISTICĂ AL REPUBLICII MOLDOVA. Indicatorii principali în agricultură [citat 22 februarie 2017]. Disponibil:

https://statistica.gov.md/pageview.php?l=ro\&idc=315\&id=2278

8. BIROUL NAŢIONAL DE STATISTICĂ AL REPUBLICII MOLDOVA. Statistica Economică. [citat 16 mai 2018]. Disponibil http://statbank.statistica.md/pxweb/pxweb/ro/ 40\%20Statistica\%20economica/?rxid=b2ff27d7-0b96-43c9-934b-42e1a2a9a774

9. CIMPOIEŞ, L. Eficienţa alocării subvenţiilor în sectorul agricol din Republica Moldova. In: Lucrări ştiinţifice. Seria Econome. Universitatea Agrară de Stat din Moldova. 2013, vol. 37, pp. 266-271. ISBN 978-9975-64-252-1.

10. Hotărîre guvernului cu privire la modul de repartizare a mijloacelor fondului de subvenţionare a producătorilor agricoli: nr. 135 din 24.02.2014 [citat 23 octombrie 2018]. Disponibil: http://lex.justice.md/md/351872/

11. Hotărîre guvernului cu privire la modul de repartizare a mijloacelor Fondului Naţional de Dezvoltare a Agriculturii şi Mediului Rural: nr. 455 din 21.06.2017. In: Monitorul Oficial al Republicii Moldova 2017, nr. 201-213, art. 537 [citat 23 octombrie 2018]. Disponibil: https://www.legis.md/cautare/getResults?doc_id=114080\&lang=ro

12. LITVIN, A., DELIU, N. Rolul subvenţiilor în susţinerea producătorilor agricoli. In: Lucrări ştiinţifice. Seria Econome. Universitatea Agrară de Stat din Moldova. 2013, vol. 37, pp. 240-243. ISBN 978-9975-64-252-1. 
13. LITVIN, A., DOBROVOLSCHI, L. Subvenţionarea - ca modalitate de susţinere şi promovare a antreprenoriatului rural în Republica Moldova. In: Lucrări ştiinţifice. Seria Econome. Universitatea Agrară de Stat din Moldova. 2013, vol. 37, pp. 227-231. ISBN 978-9975-64-252-1.

14. Politicile de subvenționare și eficiența fondului de subvenționare a agriculturii. 2017, februarie. [citat 07 martie 2020]. Disponibil: https://www.expert-grup.org/ro/biblioteca/item/1379politicile-de-subventionare-si-eficienta-fondului-de-subventionare-a-agriculturii

15. Hotărîre guvernului cu privire la aprobarea Strategiei naţionale de dezvoltare agricolă şi rurală pentru anii 2014-2020: nr. 409 din 04.06.2014. In: Monitorul Oficial al Republicii Moldova. 2014, nr. 152, art. 451 [citat 07 martie 2020]. Disponibil: https://www.legis.md/cautare/getResults?doc_id=76222\&lang=ro

16. TOMIŢA, P. Subvenţionarea producției agricole în Republica Moldova și în unele ţări ale UE. In: Lucrări ştiinţifice. Seria Econome. Universitatea Agrară de Stat din Moldova. 2013, vol. 37, pp. 7277. ISBN 978-9975-64-252-1.

17. TUURCANU, P., NIREAN, E. Asigurarea subvenţionată a riscurilor în agricultura Republicii Moldova. In: Ştiinţa agricolă. 2012, nr. 1, pp. 87-91. ISSN 1857-0003.

\section{ARTICLE HISTORY}

Received 09 April 2020

Accepted 03 June 2020 